\title{
Dragonflies and damselflies from the West of Minas Gerais, Brazil: checklist and new records
}

\author{
Diogo Silva Vilela ${ }^{1,2} * \mathbb{E}$, Ricardo Koroiva ${ }^{3} \mathbb{D}^{\text {, Thiago Henrique Azevedo Tosta }}{ }^{4}$ Marcos Carneiro Novaes $^{5}$ \& \\ Rhainer Guillermo-Ferreira ${ }^{2}$ \\ ${ }^{1}$ Universidade de São Paulo, Departamento de Biologia, Programa de Pós-Graduação em Entomologia, \\ Ribeirão Preto, SP, Brasil. \\ ${ }^{2}$ Universidade Federal de São Carlos, Departamento de Hidrobiologia, Laboratório de Estudos Ecológicos em \\ Etologia e Evolução, São Paulo, SP, Brasil. \\ ${ }^{3}$ Instituto Nacional de Pesquisas da Amazônia, Laboratório de Citotaxonomia e Insetos Aquáticos, \\ Manaus, AM, Brasil. \\ ${ }^{4}$ Universidade Federal de Uberlândia, Instituto de Biologia, Laboratório de Ecologia e Comportamento \\ de Abelhas, Uberlândia, MG, Brasil. \\ ${ }^{5}$ Universidade Estadual de Goiás, Programa de Pós-Graduação em Ambiente e Sociedade, Laboratório \\ de Ecologia Comportamental de Aracnídeos, Morrinhos, GO, Brasil. \\ *Corresponding author: Diogo Silva Vilela,e-mail: deeogoo@gmail.com
}

VILELA, D. S., KOROIVA, R., TOSTA, T. H. A., NOVAES, M. C., GUILLERMO-FERREIRA, R. Dragonflies and damselflies from the West of Minas Gerais, Brazil: checklist and new records. Biota Neotropica. 20(1): e20190851. http://dx.doi.org/10.1590/1676-0611-BN-2019-0851

Abstract: The knowledge about the richness and distribution of Brazilian dragonflies is still being unveiled. Over the years, inventories, reviews, and descriptions have been made. These contributions, apart from the taxonomic value, also provide valuable data on the occurrence of species and their distributions, which are rarely accompanied by notes about natural history and behavior. Keeping this legacy in mind, we collected dragonflies between 2011 and 2019 in Minas Gerais state, which resulted in the registration of 90 species, 41 genera and 11 families. Our results also increase distribution data, an important tool for conservation actions, and provide additional information about habitat and biology of species.

Keywords: Zygoptera, Anisoptera, biodiversity, species list, inventory.

\section{Libélulas do Oeste de Minas Gerais, Brasil: lista de espécies e novos registros}

Resumo: O conhecimento sobre a riqueza e distribuição das libélulas do Brasil ainda está sendo desvelado. Ao longo dos anos, inventários, revisões e descrições foram feitas. Essas contribuições, além do valor taxonômico, também fornecem um conjunto de dados precioso sobre a ocorrência das espécies e suas distribuições, estas que raramente são acompanhadas de anotações sobre história natural e comportamento. Mantendo este legado em mente, nós realizamos coletas de libélulas entre 2011 e 2019 no estado de Minas Gerais, o que resultou no registro de 90 espécies, 41 gêneros e 11 famílias. Nossos resultados aumentam os dados de distribuição, uma ferramenta importante para ações de conservação, e fornecem informações sobre o habitat e a biologia das espécies.

Palavras-chave: Zygoptera, Anisoptera, biodiversidade, lista de espécies, inventário. 


\section{Introduction}

Mainly in the last 80 years, the efforts spent on taxonomic studies (Santos 1944, 1945, 1950, Machado 1964, 1985, Machado et al. 1991, Lencioni 2005, 2006, 2017) and surveys (Dalzochio et al. 2011, Calvão et al. 2014, Vilela et al. 2016, Koroiva et al. 2017a, Koroiva et al. 2017b, Rodrigues \& Roque 2017) helped to cover gaps on knowledge of Brazilian odonates. Of the over 6000 hitherto described Odonata species, about 1700 are known to occur in the Neotropical region, and over 800 are recorded for Brazil (von Ellenrieder 2009, Neiss 2012). Despite these efforts, there are many species yet to be described.

In the past five years, most of the surveys generated taxonomic and distributional novelties. In a recent expedition (Oct-Nov 2015) to Chapada dos Guimarães over 100 Odonata species, one of them a new species described and two larvae of Argia (Odonata:Coenagrionidae) were recorded (Vilela, et al. 2018a,b, Cezário et a. 2018). Furthermore, Calvão et al. (2014) recorded five species new to Mato Grosso State, Brazil; Dalzochio et al. (2018) reported 182 species and seven new records to the state of Rio Grande do Sul and Rodrigues \& Roque (2017) recorded 33 species new for the state of Mato Grosso do Sul.

In the state of Minas Gerais (MG), however, few studies aimed to list Odonata species. Machado (1998) compiled records of 218 species for the entire state. Ferreira-Peruquetti \& de Marco Jr (2002) found 17 species in the municipality of Viçosa. Souza et al. (2013) recorded 57 Odonata species in the Baú Forest, municipality of Barroso, and Bedê et al. (2015) collected 128 species in Serra de São José. More recently, Machado \& Bedê (2015) described nine new species from a small area in Serra da Canastra, and Vilela et al. (2016) recorded three new species for the state, including one new to science (Guillermo-Ferreira et al. 2016).

Distributional studies are also important under a conservationist point of view since to determine if a given area needs conservational actions, the local fauna have to be taken into account. In this sense, the International Union for Conservation of Nature (IUCN 2019) relies on several types of species data, such as population size and distributional range, in order to assess the conservation status of species around the globe. IUCN is a global program for evaluating the conservation status of plant and animal species and providing some information on species habitat and biology can help to increase those conservationist actions (IUCN 2019). However, if there is a gap on the distributional data of a given species, it makes the IUCN work difficult or even impossible, disabling actions that may be taken towards the conservation of the species and its habitat. Furthermore, considering the last two great ecological disasters caused by mining in Minas Gerais (see Freitas et al. 2019), studies on the local biodiversity are crucial to know what we lose with such environmental crimes (e.g. MMA/IBAMA 2015).

Not only the species are understudied, but also some phytophisiognomies are almost unexplored. In the west of Minas Gerais, the predominant biome is the Cerrado, which presents a great array of freshwater ecosystems. Within this biome, the Veredas play an important role on the hidrology, being consisted by permanently water saturated soil and a dense vegetation, including the palm tree Mauritia flexuosa L (Fonseca 2005). Additionally, Veredas are an important source of shelter and food from insects to fishes and birds, playing an important role on the ecological balance in the Cerrado. Odonates are little explored within such areas, despite recent studies show that this ecosystem holds a great number of species of the order (Vilela et al. 2016; Barbosa et al. 2019; Borges et al. 2019).
The main objective of this study is to increase the knowledge of the geographical distribution of Odonata species.. For this, here we compile data on species from the western part of Minas Gerais State and make our database available to the academic community. In summary, our study aimed to contribute to the species conservation actions, such as the IUCN Red List of Threatened Species ${ }^{\mathrm{TM}}$ and the Latin-American Odonatological Society evaluations, which many times rely on species distributional data for assessments.

\section{Material and methods}

\section{Field sampling sites and methodology}

Altogether, we surveyed 49 localities in ten municipalities (Figure 1):

- Campina Verde (Altitude 494m): Chácara (CVC, -19.5476, -49.4936; small pond, formed by the damming of a Vereda, Figure 2d) and Granja (CVG, -19.5357, -49.5062; small pond connected to a Vereda), both sampled in February 2013.

- Guarda-Mor (Altitude 616m): Ponto 1 (GMP1, -17.7828, -47.1301; small stream) and Ponto 2 (GMP2, -17.7726, -47.1332; small stream), both sampled in December 2014.

- Ituiutaba (Altitude 605m): Lagoa Temporária (ITBL, -18.9776, -49.4103; temporary pond) in April 2014; Ribeirão São Lourenço (ITBSL, -18.9853, -49.4179 and -19.0611,-49.3213; medium order stream, Figure 2e) sampled in December 2013 and April 2014; Rio Tijuco (ITBT, -18.9418,-49.4768; $-18.9209,-49.5664$ and $-18.9525,-49.3377$; medium sized river, Figure 2f) sampled in December 2011 and March 2012; Estância Paraíso (EPA, -18.9522, -49.3399; small stream connected to a river, Figure 2g) sampled in April 2014.

- Matutina (Altitude 1060m, Figure 2h): Matutina 1 (MAT1, -19.1377, -46.0669; small stream connected with a Vereda), Matutina 2 (MAT2, -19.1251, -46.0568; small pond), Matutina 3 (MAT3, -19.1563, -46.0369; small stream) and Matutina 4 (MAT4, -19.1221, -46.0673; small stream) all sampled in March 2015.

- $\quad$ Paracatu (Altitude 688m): Ranchão (PAR, -16.8608, -46.9811; stream connected with a Vereda, Figure 2c) sampled in July 2014.

- $\quad$ Prata (Altitude 631m): Rodovia (PRA, -19.3210, -48.9454; stream connected with a Vereda) sampled in October 2012.

- São Roque de Minas, Serra da Canastra (Altitude 819-1300m): Cachoeira Rio do Peixe (CRP, -20.2569, -46.4096; small stream by a waterfall, Figure 2a), Aqueduto (AQD, -20.2648, -46.3968; stream near to a Vereda), Riacho Costela de Vaca (RCV, -20.2658, -46.3957; stream near to a Vereda), Cerradão (CER, -20.1914, -46.3858; stream near to a Vereda, Figure 2b), Barro Sujo (BS, -20.2145, -46.3808; small stream), Cerca elétrica (CE, $-20.2385,-46.3847$; stream near to a Vereda), Espraiado (Subida) (ESS, -20.2411, -46.3857; stream near to a Vereda), Rio São Francisco (RSF, -20.3330, -46.4361; large river), Água Branca (AGB, -20.2922, -46.3658; small stream), Cachoeira da Chinela (CHI, -20.3002, -46.3955; stream by a waterfall), Casca D'anta (CCD, -20.2974, -46.5227; stream by a waterfall), Rolinho (RL, -20.1706, -46.5615; small stream near a Vereda), Nascente (NAS, -20.2433, -46.4463; 

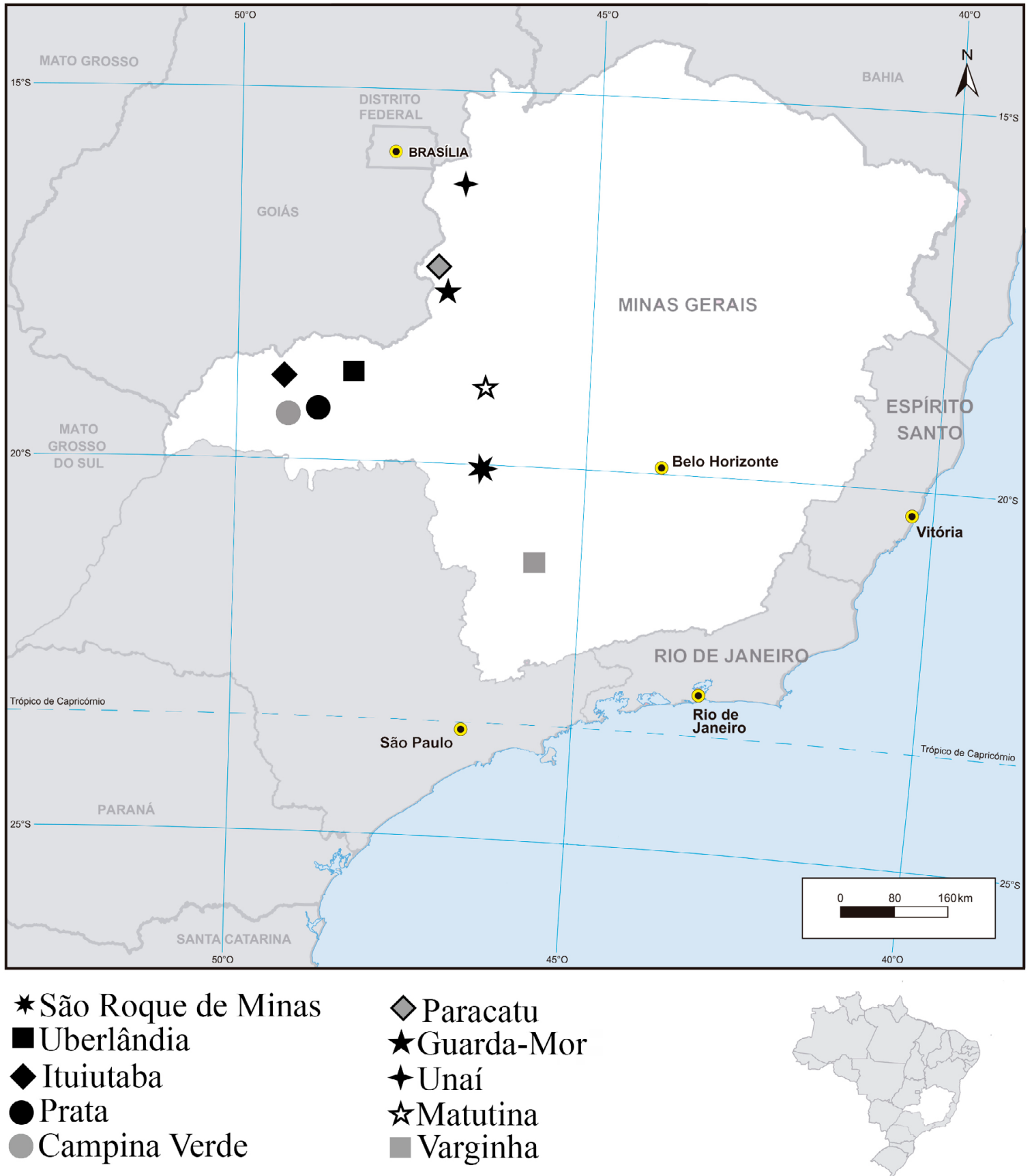

Figure 1. Map of Minas Gerais state, southeast Brazil, showing the ten sampled municipalities.

small stream connected to a Vereda), Ponte 1 (PO1, -20.2402, -46.5875 ; small stream connected to a Vereda), Ponte 2 (PO2, -20.2325, -46.6083; small stream connected to a Vereda), Quintal da Canastra (QUI, -20.3282,-46.5038; large pond), Cachoeira da Capivara (CPV, -20.6287,-46.2863; large stream by a waterfall), Lago Tio Zezico (ZZC, -20.3121,-46.5319; small pond), Córrego Tio Zezico (ZZC, -20.3116,-46.5324; stream), Lago P31 (P31, -20.1656,-46.6877; two small ponds within a Vereda), Riacho Sr. Vicente (VCT, -20.3033,-46.5492; ; small stream connected to a Vereda), Córrego Guariba (GUA, -20.3017,-46.5483; small stream near a Vereda), Córrego
Passageiro (PSG, -20.2668,-46.5554; small stream with rocky bottom), Córrego Rasga Canga (CAN, -20.1761,-46.5603; stream by a waterfall), Portaria Sul (SUL, -20.3063,-46.5236; small stream), Portaria 2 (PR2, -20.1523,-46.6605; small stream by a waterfall), Centro de Visitantes (VIS, -20.2541,46.4168; small stream) sampled in May and October 2017, March and November 2018 and April 2019.

- Uberlândia (Altitude $863 \mathrm{~m}$ ): Marileuza (UDI,-18.8712, -48.2481 ; small stream near a Vereda, which nowadays is turning to a habitation area) sampled in February 2015. 

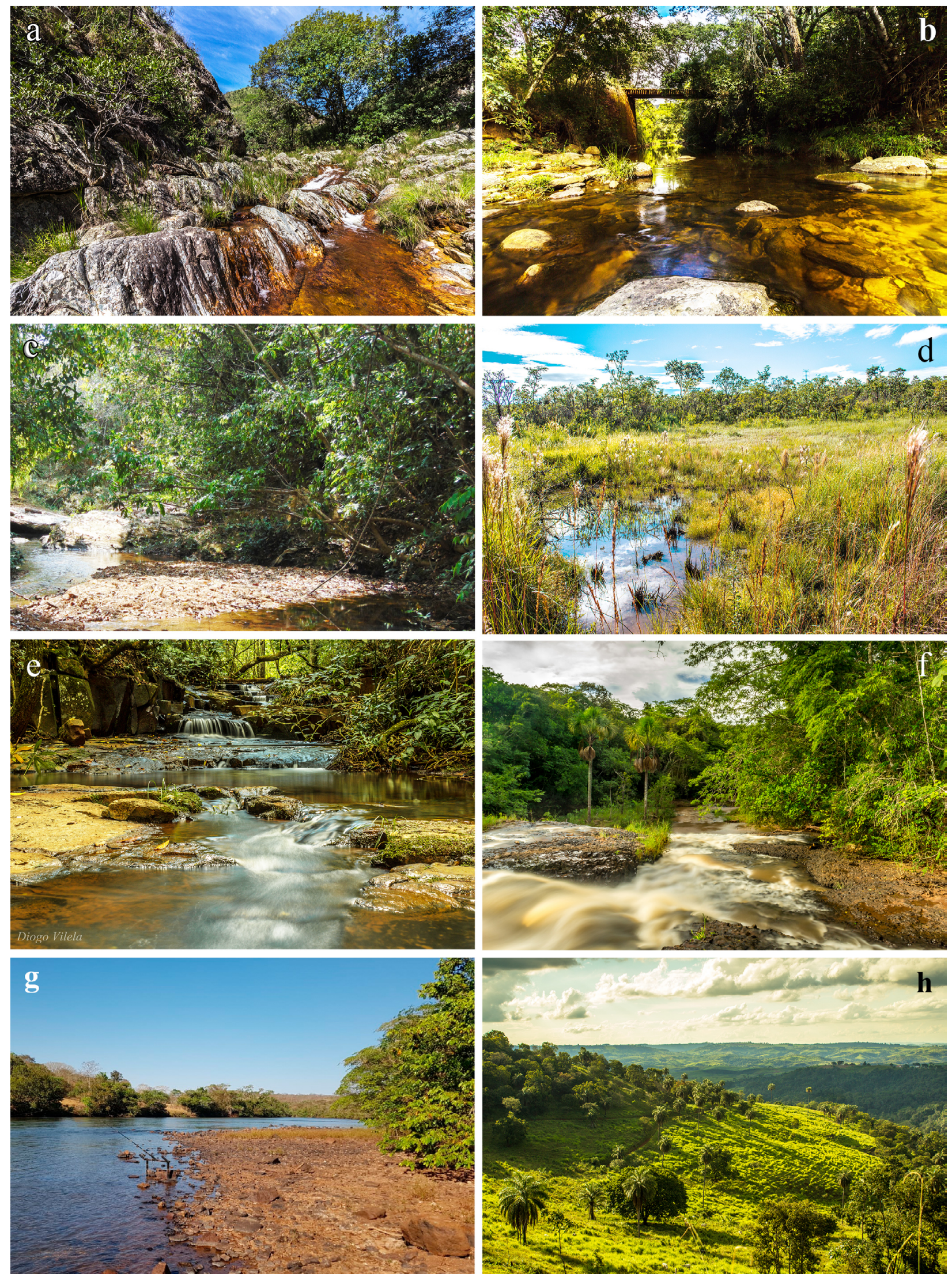

Figure 2. Some of the sampled sites in this study: a. Cachoeira Rio do Peixe (CRP), São Roque de Minas; b. Cerradão (CER), São Roque de Minas; c. Ranchão (PAR), Paracatu; d. Chácara (CVC), Campina Verde; e. Ribeirão São Lourenço (ITBSL), Ituiutaba; f. Rio Tijuco (ITBT), Ituiutaba; g. Estância Paraíso (EPA), Ituiutaba; h. Landscape between Matutina 3 (MAT3) and Matutina 4 (MAT4), Matutina. 
- Unaí (Altitude 640m): Lagoa-Riacho (UNAI, -16.4822, -47.4149 ; medium order river and a pond) sampled in July 2014.

- Varginha (Altitude 915m): Sítio Juriti (SRI, -21.5854, -45.4070; small pond), Carro Velho (CAR, -21.5901, -45.3721; small stream), Lagoa Soberana de Minas Jorge (JOR, -21.6289, -45.4342; small stream and pond), Faz. Tachos (TCH, -21.6154, -45.4803; small stream) sampled in June 2018.

The collections were made ad libitum in different hours of the day, for at least one hour per site, always between 8:00 to 14:00h. An entomological net was used to collect the specimens and they were placed in individual paper envelopes. The collection authorization process was issued by IBAMA, through SISBio system under the numbers 53026-3 and 54386-6. The identifications were made using the keys of Lencioni (Lencioni 2005, 2006, 2017) and Garrison et al. $(2006,2010)$. The specimens collected are deposited in the Laboratory of Ecological Studies on Ethology and Evolution (LESTES, UFSCar), São Carlos, São Paulo and in the personal collection of Frederico Lencioni in Jacareí, São Paulo.

During fieldwork, we observed and noted the following behavioral traits: (i) territoriality status, (ii) mate-guarding behavior and (iii) oviposition behavior. Such behavioral traits are important because they reveal important aspects of reproductive tactics, habitat occupancy and selection, competition and even larval development (Corbet 1999).

When not possible to notice behavioral traits on the moment of collections, we searched for such information on the literature on two online platforms (Google scholar: https:/goo.gl/MtXqZN; Scopus: https://goo.gl/2F36gs) with the terms "species name", "behavior", "behaviour". The terms were used all together, in different orders and separately along with the species names. For example: "Tigriagrion aurantinigrum" "behavior" "behaviour" or solely "Tigriagrion aurantinigrum".For every sampled species, we checked the IUCN conservation status (iucnreslist.org) (IUCN 2019). When a species is assessed by specialists, a code is given to represent its conservational status. For example, if a species is lacking distributional data and nothing much is known of its conservational situation, it is given to it a data deficient status, or DD. Other classification status are: LC (least concern), when a species is well distributed, occurring in many localities, including protected areas; NT (near threatened), when its assessment indicates any degree of conservational threat, usually applied to species occurring near expanding urban areas, which can be threatened in a near future; VU (vulnerable), species facing extinction risk in nature, with a limited distributional range $\left(<5000 \mathrm{~km}^{2}\right)$ in areas threatened by human activities; CR (critically endangered), species inhabiting areas less than $100 \mathrm{~km}^{2}$, occurring in usually one locality, often threatened by human activities.

The map was adapted from IBGE - Brazilian Geography and Statistics Institute (2019) using Adobe Photoshop 2017.1.1. Habitus scan of species was made using an EPSON V600 Perfection and posterior plate assembling using Adobe Photoshop 2017.1.1. Photographs of the sampling sites were all made by the authors, except for (Fig. 3g), courtesy of Edson Soares dos Santos.

\section{Results}

\section{Sampled species}

We collected individuals from 11 families, 41 genera and 90 species (Table 1; Figure 3a-1). The family Libellulidae was the most representative of Anisoptera, with 13 genera and 27 species, whereas Coenagrionidae was the most specious family of Zygoptera, with 12 genera and 35 species (Table 1). PAR was the most speciose site with 16 records, whereas NAS recorded 15 species and ITBT and UNAI recorded 14 species each. On the other hand, VIS and RL were the least specious site with one species each (Table 2).

Table 1. Representation of each collected family by genera and species in 49 sampling points distributed in the State of Minas Gerais, Brazil.

\begin{tabular}{llcc}
\hline Anisoptera & Aeshnidae & $\begin{array}{c}\text { Number of } \\
\text { genera }\end{array}$ & $\begin{array}{c}\text { Number of } \\
\text { species }\end{array}$ \\
\hline \multirow{2}{*}{ Zygoptera } & Corduliidae & 1 & 5 \\
& Gomphidae & 3 & 1 \\
& Libellulidae & 13 & 4 \\
& Calopterygidae & 27 \\
& Coenagrionidae & 12 & \\
& Dicteriadidae & 1 & 7 \\
& Heteragrionidae & 1 & 1 \\
& Lestidae & 1 & 4 \\
& Megapodagrionidae & 1 & 3 \\
& Protoneuridae & 1 & 2 \\
\hline Total & 11 Families & 41 & 90 \\
\hline
\end{tabular}

Furthermore, Machado (1998) reported 218 Odonata species to Minas Gerais state. Therefore, adding new species descriptions $(n=29)$ and new records $(\mathrm{n}=22)$ since 1998 , the number raises to 269 species to Minas Gerais (Table 3).

\section{First records and new species}

We found two new records of odonate species for Minas Gerais, one belonging to Coenagrionidae and the other to Calopterygidae: Neoneura waltheri Selys and Hetaerina hebe Selys, respectively. Also, we found a new species from the Heteragrionidae family: Heteragrion denisye Vilela, Koroiva and Guillermo-Ferreira.

Hetaerina hebe Selys, three males (Figure 3h): This species is recorded in the states of Rio de Janeiro (Santos 1970) and São Paulo (Lencioni 2017). Our specimens of $H$. hebe were found in streams with channel shading by riparian vegetation and presence of rapids in sampling sites of Varginha and Serra da Canastra. We have noticed females perform endophytic oviposition.

Neoneura waltheri Selys, one male (Figure 3i): Neoneura waltheri occurs in Brazil and Argentina. There are records of this species in the 

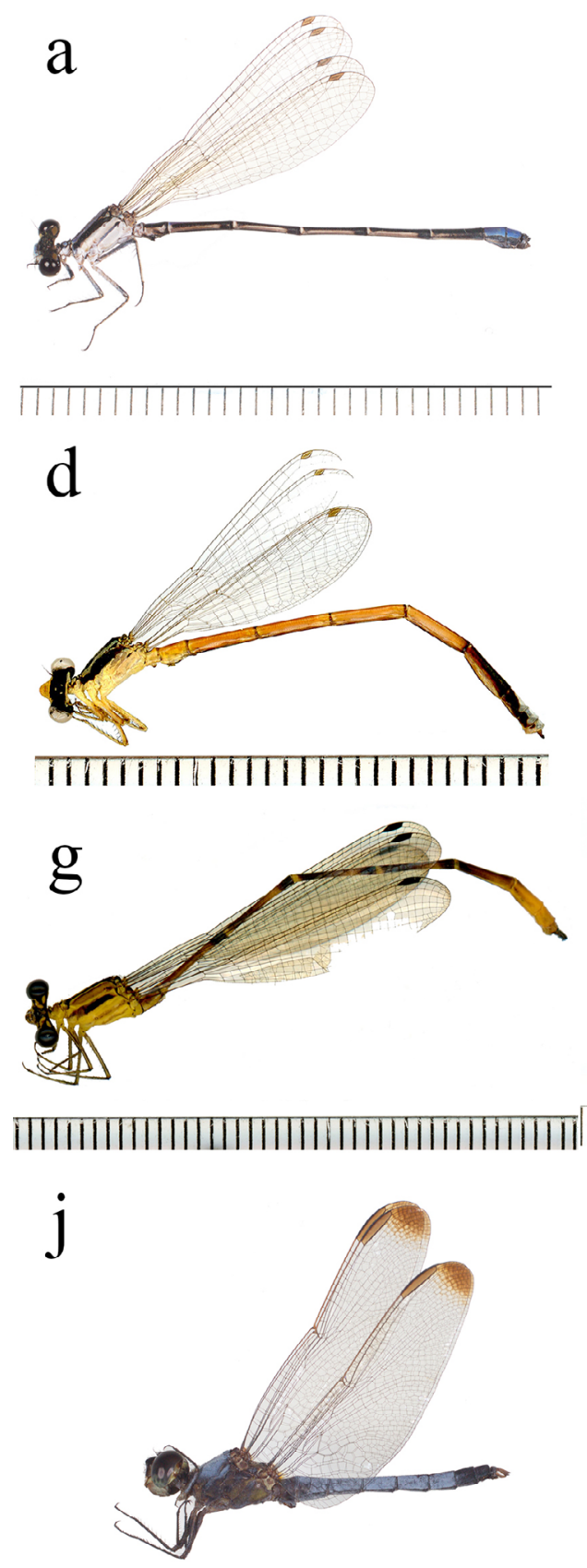

1111111111111111111111111111111

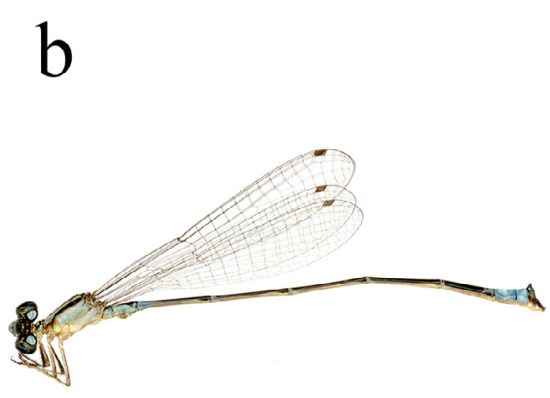

C

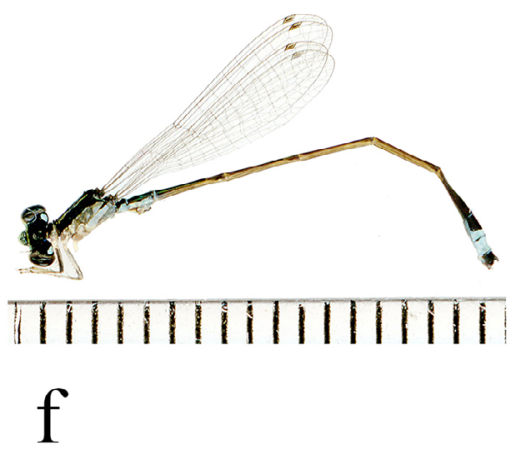

e
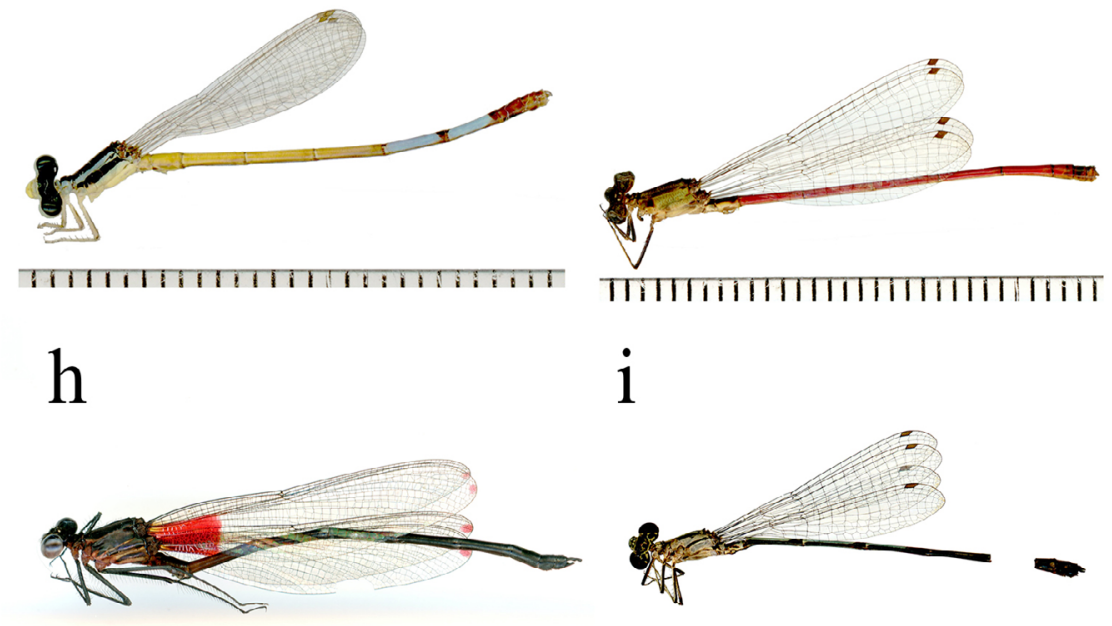

i

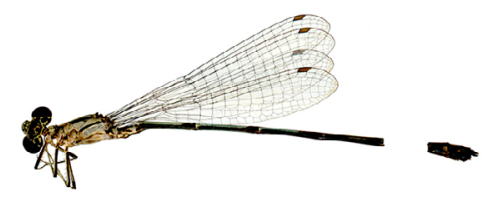

IIIIIIIIIIIIIIIIIIIIIIIIIIIIIII
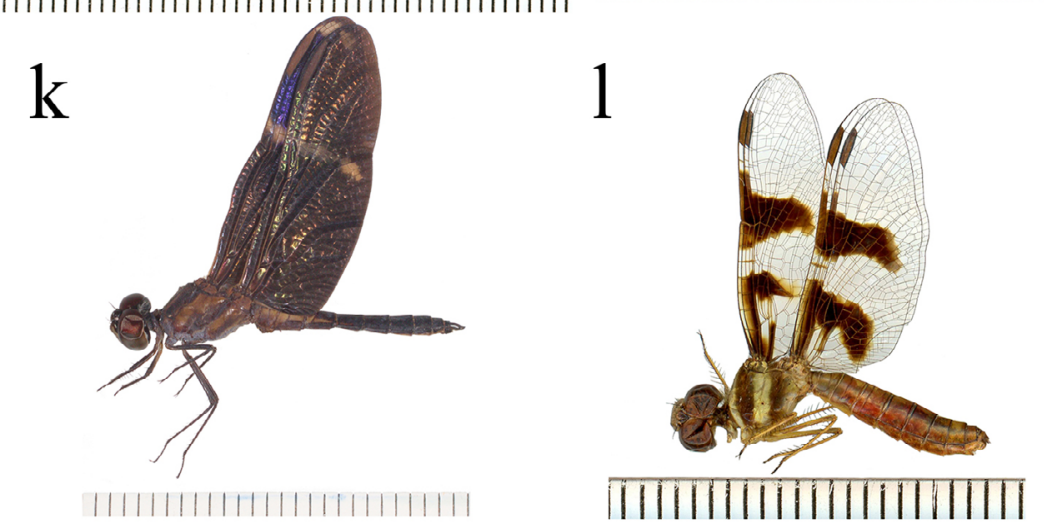

Figure 3. Habitus scan of some species sampled in our expeditions: a. Argia lilacina Selys; b. Acanthagrion aepiolum Tennessen; c. Ischnura capreolus Hagen; d. Minagrion waltheri Selys; e. Minagrion franciscoi Machado \& Bedê; f. Oxyagrion chapadense Costa; g. Heteragrion triangulare Hagen in Selys; h. Hetaerina hebe Selys; i. Neoneura waltheri Selys; j. Erythrodiplax ana Guillermo-Ferreira, Vilela, Del-Claro \& Bispo; k. Zenithoptera lanei Santos; 1. Perithemis mooma Kirby.

states of Rio de Janeiro and Paraná. Specimens collected at the margins of the Tijuco River in Ituiutaba were perched in a clump of Elionurus sp. Jurzitza (1981), made some observations on specimens in National Park of Iguazu, Argentina. We have noticed females perform endophytic oviposition in tandem with the male, at running waters.

Heteragrion denisye Vilela, Koroiva and Guillermo-Ferreira, one male: this species was recently described (Vilela et al. 2019) inhabiting altitude fields within the Serra da Canastra National Park. We only found one specimen despite sampling the type location in two occasions. This species is peculiar because was found in small bushes in an open area, whereas other Heteragrion species are known to inhabit shaded areas with gallery woods.

\section{Endemic and peculiar species}

In addition to these records, we collected some of the endemic species of Serra da Canastra described by Machado \& Bedê (2015), 
Odonata from West Minas Gerais

Table 2. Sampled localities with the respective number of species collected on each site.

\begin{tabular}{|c|c|c|}
\hline Locality & Code & N. Species \\
\hline Paracatu & PAR & 16 \\
\hline Nascente & NAS & 15 \\
\hline Rio Tijuco & ITBT & 14 \\
\hline Unaí & UNAI & 14 \\
\hline Ribeirão São Lourenço & ITBSL & 12 \\
\hline Marileuza & UDI & 12 \\
\hline Matutina Ponto 2 & MAT2 & 10 \\
\hline Quintal da Canastra & QUI & 10 \\
\hline Cachoeira da Capivara & CPV & 9 \\
\hline Cachoeira Rio do Peixe & CRP & 9 \\
\hline Aqueduto & AQD & 8 \\
\hline Cerradão & CER & 8 \\
\hline Rio São Francisco & RSF & 8 \\
\hline Lago Tio Zezico & $\mathrm{LZZ}$ & 8 \\
\hline Córrego Tio Zezico & $\mathrm{ZZC}$ & 7 \\
\hline Carro Velho & CAR & 7 \\
\hline Fazenda Sr. Gilberto & GIL & 7 \\
\hline Granja & $\mathrm{CVG}$ & 7 \\
\hline Guarda Mor Ponto 1 & GMP1 & 7 \\
\hline Matutina Ponto 4 & MAT4 & 7 \\
\hline Prata & PRA & 7 \\
\hline Lago P31 & $\mathrm{P} 31$ & 6 \\
\hline Guarda Mor Ponto 2 & GMP2 & 6 \\
\hline Matutina Ponto 1 & MAT1 & 6 \\
\hline Riacho Costela de Vaca & $\mathrm{RCV}$ & 6 \\
\hline Espraiado (Subida) & ESS & 6 \\
\hline Cachoeira da Chinela & $\mathrm{CHI}$ & 6 \\
\hline Lagoa Temporária & ITBL & 5 \\
\hline Matutina Ponto 3 & MAT3 & 5 \\
\hline Ponte 1 & PO1 & 5 \\
\hline Ponte 2 & $\mathrm{PO} 2$ & 5 \\
\hline Riacho Sr. Vicente & $\mathrm{VCT}$ & 5 \\
\hline Fazenda dos Tachos & $\mathrm{TCH}$ & 4 \\
\hline Chácara & $\mathrm{CVC}$ & 4 \\
\hline Barro Sujo & BS & 4 \\
\hline Casca D'Anta & $\mathrm{CCD}$ & 4 \\
\hline Cerca & $\mathrm{CE}$ & 4 \\
\hline Córrego Guariba & GUA & 4 \\
\hline Córrego Passageiro & PSG & 4 \\
\hline Córrego Rasga Canga & CAN & 4 \\
\hline Portaria Sul & SUL & 4 \\
\hline Portaria 2 & PR2 & 3 \\
\hline Sítio Juriti & SRI & 3 \\
\hline Lagoa S. M. Jorge & JOR & 3 \\
\hline Água Branca & AGB & 3 \\
\hline Alojamento (P17) & $\mathrm{P} 17$ & 2 \\
\hline Estância Paraíso & EPA & 2 \\
\hline Centro de Visitantes & VIS & 1 \\
\hline Rolinho & $\mathrm{RL}$ & 1 \\
\hline
\end{tabular}

Table 3. List of new Odonata species and new records to the state of Minas Gerais, published after 1998 .

\begin{tabular}{|c|c|c|c|}
\hline Author & Year & Type of data & $\begin{array}{c}\text { Number of } \\
\text { records }\end{array}$ \\
\hline Machado & 2000 & New species & 1 \\
\hline Costa et al. & 2000 & New species & 1 \\
\hline Machado & 2002 & New species & 1 \\
\hline Tennessen & 2004 & New species & 1 \\
\hline Machado & $2005 \mathrm{a}$ & New species & 1 \\
\hline Machado & $2005 b$ & New species & 1 \\
\hline Garrison & 2006 & New species & 1 \\
\hline Machado & 2006 & New species & 1 \\
\hline Machado \& Bedê & 2006 & New species & 1 \\
\hline Machado & $2007 \mathrm{a}$ & New species & 1 \\
\hline Machado & $2007 b$ & New species & 1 \\
\hline Pessacq \& Costa & 2007 & New species & 2 \\
\hline Costa et al. & 2009 & New species & 1 \\
\hline Santos et al. & 2010 & New species & 1 \\
\hline Machado & 2010 & New species & 1 \\
\hline Almeida et al. & 2013 & New record & 1 \\
\hline Machado & 2014 & New species & 1 \\
\hline Machado & 2015 & New species & 1 \\
\hline Machado \& Bedê & 2015 & New species & 7 \\
\hline Bedê et al. & 2015 & New records & 6 \\
\hline Guillermo-Ferreira et al. & 2016 & New species & 1 \\
\hline Vilela et al. & 2016 & New record & 1 \\
\hline Pinto \& Almeida & 2016 & New species & 1 \\
\hline Ávila-Júnior et al. & 2017 & New species & 1 \\
\hline De Souza et al. & 2017 & New records & 7 \\
\hline Borges et al. & 2018 & New records & 1 \\
\hline Barbosa et al. & 2019 & New records & 6 \\
\hline Vilela et al. & 2019 & New species & 1 \\
\hline \multirow[t]{2}{*}{ This study } & & New records & 2 \\
\hline & & Total & 51 \\
\hline
\end{tabular}

such as Franciscagrion franciscoi Machado \& Bedê, Franciscagrion longispinum Machado \& Bedê, Franciscobasis franciscoi Machado \& Bedê, Franciscobasis sonia Machado \& Bedê, Minagrion franciscoi Machado \& Bedê (Fig. 2e) and Oxyagrion franciscoi Machado \& Bedê. Despite the extensive sampling effort throughout western region of Minas Gerais, these species remain restricted to the Serra da Canastra National Park.

Given our large sampling size, some hard to sample species were collect in Serra da Canastra such as Limnetron debile Karsch and Neocordulia volxemi Selys, both at sites with running water and little shaded areas. Additionally, the larvae of Castoraeschna corbeti Carvalho, Pinto \& Ferreira, a possible new Libellulidae species and the hitherto undescribed female of Mnesarete rhopalon Garrison were also sampled. 


\section{Behavioral and ecological traits}

As most of the collections were made in the course of an hour, freshwater habitat selection was the only ecological trait that could be inferred for all species. We emphasize that some of the observed traits were already reported in the literature and the data observed by us are highlighted in bold (Table 4).
Data on behavioral traits are derived from personal observations or from literature: territoriality status, mate-guarding behavior and oviposition behavior. Of all traits possible, however, 168 (63\%) were not found on the literature or observed in our field study (i.e. ND). Moreover, 40 (45\%) of all species had no behavioral information available. Territoriality was the most representative trait, determined for

Table 4. Odonata species collected in this study with information about freshwater habitat selection, territoriality status, mate-guarding (MGB) and oviposition behavior. LE: lentic habitat; LO: lotic habitat; FA: female alone; IT: in tandem; NC: no contact; T: territorial; NT: non-territorial; EX: exofitic oviposition; END: endofitic oviposition; PE: percher; FL: flier; IUCN Status: LC (least concern), DD (data deficient); ND: no data recorded in the study area or literature. * First record to Minas Gerais State; ** Under evaluation by IUCN specialists. Traits in bold were observed in this study.

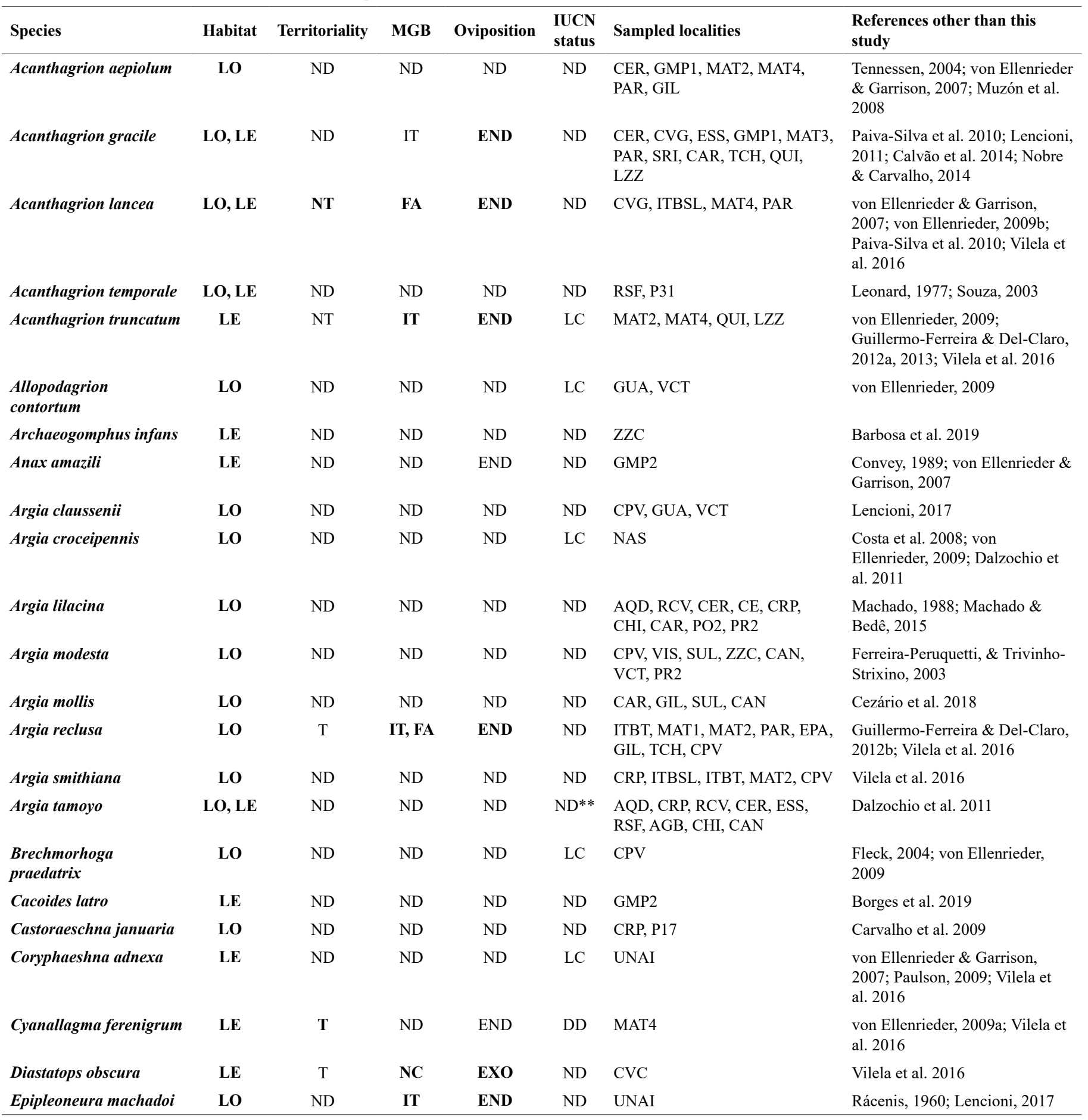


Continuation Table 4.

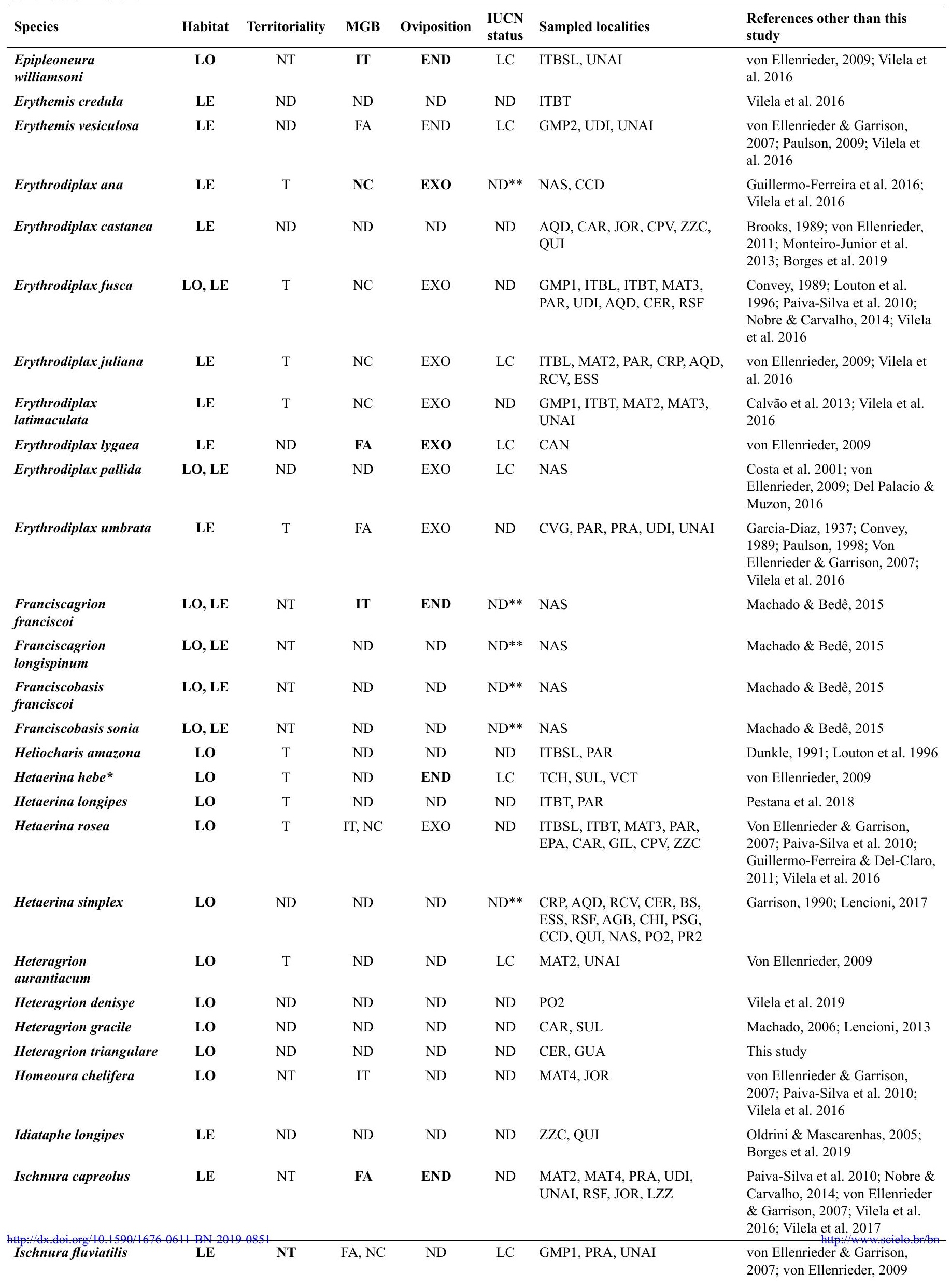


Vilela, D.S. et al.

Continuation Table 4.

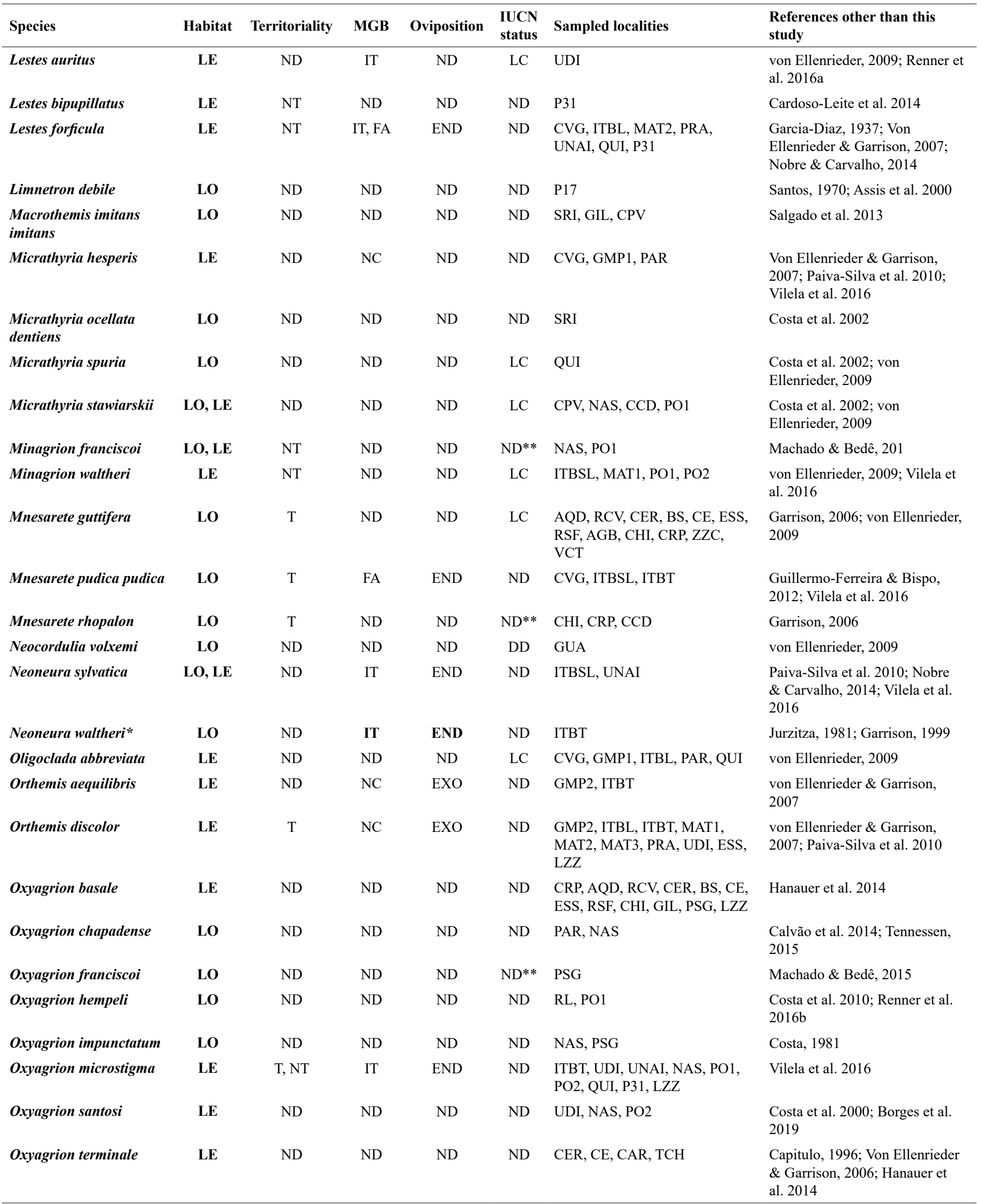


Continuation Table 4.

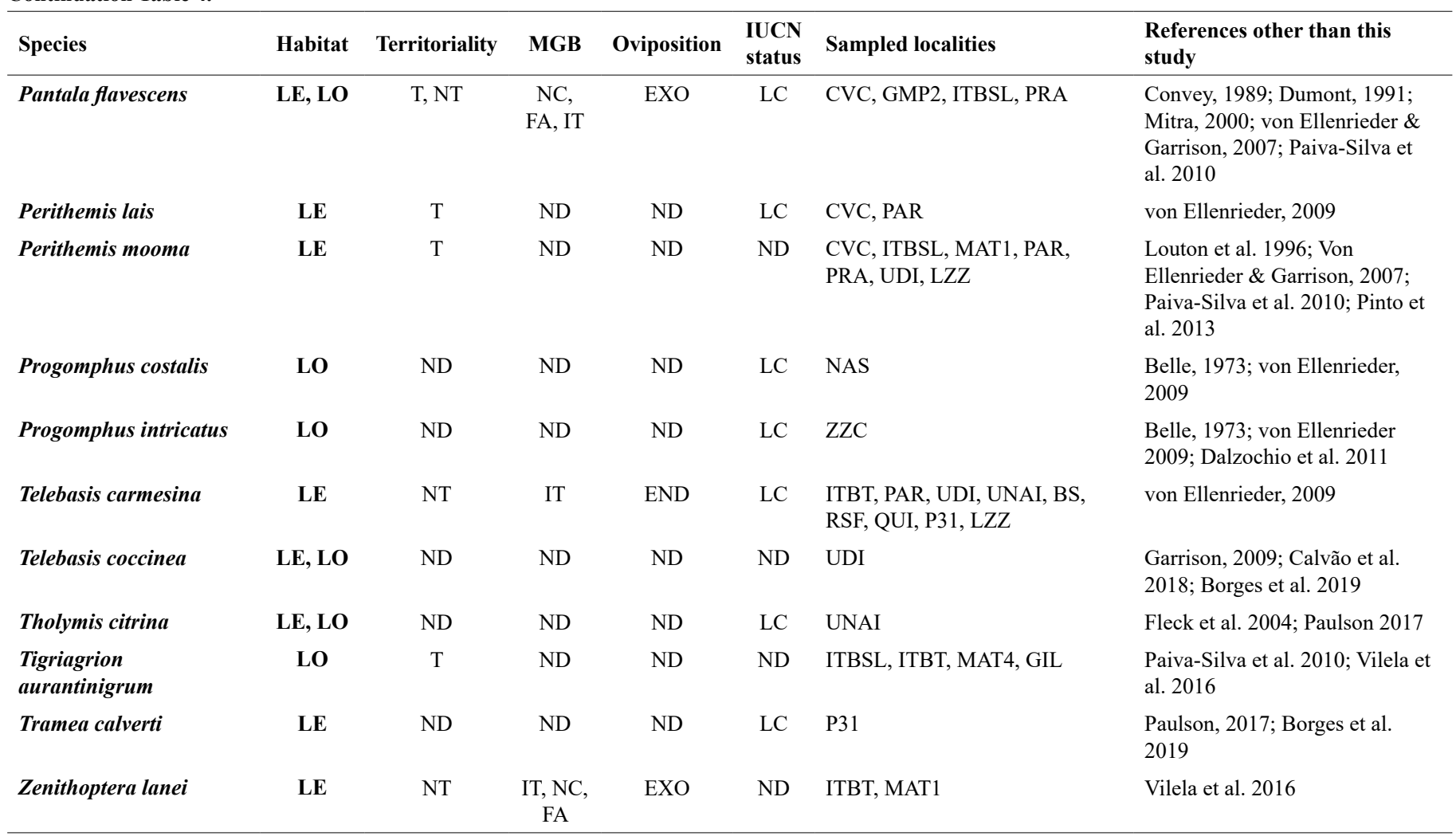

$38(42 \%)$ of the species. Mate-guarding behavior (MGB) and oviposition were determined for 31 (35\%) species (Table 4).

\section{IUCN status}

The IUCN conservational status was available for only 28 (31.5\%) of the sampled species. Most of the evaluated species (26 out of 28) were assessed as being Least Concern by IUCN classification, whereas for Cyanallagma ferenigrum de Marmels and Neocordulia volxemi Selys are classified as Data Deficient (DD) (Table 4).

\section{Discussion}

After this study, with 269 recorded species, Minas Gerais is the Brazilian State with the second highest number of Odonata species, considering that Rio de Janeiro has recorded 280 species (Costa \& Santos 2000), followed by São Paulo, 251 species (Costa, Machado, et al. 2000), Mato Grosso do Sul, 209 species (Rodrigues et al. 2018, Koroiva et al. 2017b), Rio Grande do Sul, 182 species (Dalzochio et al. 2018), and Goiás and the Distrito Federal, 152 species (Nóbrega \& De Marco 2011). Obviously, such numbers reflect the areas where most Brazilian odonatologists explored, and the northern States of Brazil may concentrate an even higher number of species.

Concerning the sampled areas, 18 of the 49 sites were at or near Veredas, 24 areas were consisted of streams, rivers and waterfalls, and only seven of them were ponds. This consists, so far, in the most extensive (in number of species recorded and sampled areas) study of odonates in the State of Minas Gerais. Among the sampled sites, the Veredas were mostly well preserved, however few (five out of 18) of them were placed in protected areas. In fact, the Vereda in Uberlândia
(UDI) is already threatened by a urbanization project with housing activities. Such anthropic pressure may permanently impact on the faunal composition of this and other unprotected areas, as Vereda areas do not regenerate after a severe disturbance (Guimarães et al. 2002; Oliveira et al. 2009).

Bearing in mind the information on species behavior, we provide a list of behavioral traits of our focal observations and the ones found in the literature. Despite being available for $55 \%$ of the sampled species, most of the information on species biology is underexplored, what requires data from more than one source per species to build a more complete behavioral perspective. Considering that only 40 of 90 species have biological information, it is important to know how much to we must advance in this sense. Although neglected, behavioral diversity is an important species feature, for it reveals a cryptic biodiversity (Cordero-Rivera 2017). For instance, for species that are morphologically similar but behave in different ways, the behavioral repertoire can be a distinguishable trait between them (GuillermoFerreira \& Bispo 2012, Cordero-Rivera 2017).

Here, we also show that few species were assessed regarding their conservational status. Considering the current measures from the Latin-American Odonatological Society and IUCN to assess all Latin-American odonate species, our results make a great contribution to this effort. The IUCN evaluations require data of distribution ranges, altitude of occurrence, population status, and biological data (IUCN 2019). Therefore, the more information one can gather about a species, more precisely it can be evaluated. In our study, only $31.5 \%$ of the sampled species were already assessed by IUCN. Most of these species fit in the Least Concern category, which means that, although some of the species may be widespread and out of risk (IUCN 2019), others that 
were not assessed may be under threat. For Cyanallagma ferenigrum de Marmels and Neocordulia volxemi Selys, the status appears as Data Deficient, which means that, at the moment of the assessment, the data available for evaluation were insufficient to set a conservational status to these species (IUCN 2019). Our records for this two species and the others that were not assessed will help in ongoing assessments. The results presented here respect the guidelines of the Latin-American Odonatological Society and are being used to assess Neotropical species conservation status. Finally, we suggest that research focus on studies of natural history and distributional ranges that cover understudied species (Data Deficient and unevaluated species) in the Cerrado biome (mainly on Veredas) to ensure a broader perspective on the Neotropical odonate fauna.

\section{Acknowledgments}

DSV thanks Conselho Nacional de Desenvolvimento Científico e Tecnológico (CNPq) for a scholarship grant (Proc.140732/2016-0). RK thanks PNPD/CAPES and FIXAM-I/FAPEAM (Edital $n^{\circ} 05 / 2018$; Proc.062.01503/2018) for providing post-doc scholarships. THAT thanks CAPES for providing doctoral scholarship. RGF thanks Fundação de Amparo à Pesquisa do Estado de São Paulo (FAPESP) for constant support. We thank Douglas Riff, Carlos A. F. Vilela, Denisy A. Silva, Leonardo Ricoli, Rodrigo Cezário, Tatiene Zenni, Vinícius Lopez, Vanessa Gomes, Ricardo Paiva Vallim and Amanda Crivelaro for field support. DSV, RGF and MCN would like to thank The Mohamed Bin Zayed Conservation Fund for a grant that allowed us to collect at the Serra da Canastra National Park. RK, DSV and RGF also would like to thank The Rufford Foundation for a grant that allowed us to collect at the Serra da Canastra National Park (RSG 25133-2). This study was partly financed by the Coordenação de Aperfeiçoamento de Pessoal de Nível Superior - Brasil (CAPES) - Finance Code 001.

\section{Author contributions}

Diogo Silva Vilela: Contribution to data collection and manuscript preparation. Substantial contribution in the concept and design of the study. Contribution to critical revision, adding intelectual content.

Ricardo Koroiva: Contribution to data collection and manuscript preparation. Substantial contribution in the concept and design of the study. Contribution to critical revision, adding intelectual content.

Thiago Henrique Azevedo Tosta: Contribution to data collection and manuscript preparation. Contribution to critical revision, adding intelectual content.

Marcos Carneiro Novaes: Contribution to manuscript preparation. Contribution to critical revision, adding intelectual content.

Rhainer Guillermo-Ferreira: Contribution to data collection and manuscript preparation. Contribution to critical revision, adding intelectual content.

\section{Conflicts of interest}

The authors declare that they have no conflict of interest related to the publication of this manuscript.

\section{References}

ALMEIDA, M.V.O. de, PINTO, Â.P., CARVALHO, A. do L. \& TAKIYA, D.M. 2013. When rare is just a matter of sampling: unexpected dominance of clubtail dragonflies (Odonata, Gomphidae) through different collecting methods at Parque Nacional da Serra do Cipó, Minas Gerais State, Brazil. Rev. Bras. Entomol. 57(4):417-423.

ASSIS, J.C.F., CARVALHO, A.L. \& DORVILLÉ, L.F.M. 2000. Aspects of larval development of Limnetron debile (Karsch), in a mountain stream of Rio de Janeiro State, Brazil (Anisoptera: Aeshnidae). Odonatologica 29(2):151-155.

ÁVILA-JUNIOR, W.F., LENCIONI, F.A. \& CARNEIRO, M.A.A. 2017. Heteragrion cauei sp. nov., a new damselfly from Minas Gerais, Brazil (Odonata: Heteragrionidae). Odonatologica 46(3/4):275-286.

BARBOSA, M.S., BORGES, L.R., VILELA, D.S., VENÂNCIO, H. \& SANTOS, J.C. 2019. Odonate Communities of the Sucupira Reservoir, Rio Uberabinha, Minas Gerais, Brazil. Pap. Avulsos Zool. 59e20195922.

BEDÊ, L.C., MACHADO, A.B.M., PIPER, W. \& SOUZA, M.M. 2015. Odonata of the Serra de São José-Brazil's first Wildlife Reserve aimed at the conservation of dragonflies. Not. Odonatol. 8(5):117-155.

BELLE, J. 1973. A revision of the New World genus Progomphus Selys, 1854 (Anisoptera: Gomphidae). Odonatologica (2):191-308.

BORGES, L.R., BARBOSA, M.S., CARNEIRO, M.A.A., VILELA, D.S. \& SANTOS, J.C. 2019. Dragonflies and damselflies (Insecta: Odonata) from a Cerrado area at Triângulo Mineiro, Minas Gerais, Brazil. Biota Neotrop. 19(1): e20180609. http://dx.doi.org/10.1590/1676-0611-bn-2018-0609 (last access on 26/07/2019)

BROOKS, S.J. 1989. Odonata collected from Guanacaste National Park, Costa Rica, July 1988. Not. Odonatol. 3(4):49-52.

CALVÃO, L.B., JUEN, L., DE OLIVEIRA JUNIOR, J.M.B., BATISTA, J.D. \& DE MARCO JÚNIOR, P. 2018. Land use modifies Odonata diversity in streams of the Brazilian Cerrado. J. Insect Conserv. 22(5-6):675-685.

CALVÃO, L.B., DE MARCO, P.J. \& BATISTA, J.D. 2014. List Odonata (Insecta) from Nova Xavantina, Mato Grosso, Central Brazil: Information on species distribution and new records. Check List 10(2):299-307.

CAPÍTULO, A.R. 1996. Description of the last instar larva of Tauriphila risi Martin (Anisoptera: Libellulidae). Odonatologica 25(4):391-395.

CARDOSO-LEITE, R., VILARDI, G.C., GUILLERMO-FERREIRA, R. \& BISPO, P.C. 2014. The Effect of Conspecific Density on Emergence of Lestes bipupillatus Calvert, 1909 (Odonata: Lestidae). Psyche A J. Entomol. 2014:1-3.

CARVALHO, A.L., PINTO, Â.P. \& FERREIRA-JR, N. 2009. Castoraeschna corbeti sp. nov. from Floresta Nacional de Carajés, Paré state, Brazil (Odonata: Aeshnidae). Int. J. Odonatol. 12(2):337-346.

CEZÁRIO, R.R., VILELA, D.S. \& GUILLERMO-FERREIRA, R. 2018. Final instar larvae of Argia mollis Hagen in Selys, 1865 and Argia smithiana Calvert, 1909 (Odonata: Coenagrionidae) from the Brazilian Cerrado. Zootaxa 4514(1):137.

CONVEY, P. 1989. Odonata from the Paria Peninsula, in the eastern Coastal Cordillera of Venezuela. Not. Odonatol. 3:55-59.

CORBET, P.S. 1999. Dragonflies: behavior and ecology of Odonata. Comstock Publ. Assoc, Ithaca.

CORDERO-RIVERA, A. 2017. Behavioral Diversity (Ethodiversity): A Neglected Level in the Study of Biodiversity. Front. Ecol. Evol. 5(7):1-7.

COSTA, J.M. 1981. Contribuição ao estudo das formas larvárias do gênero Oxyagrion Selys, 1876, com a descrição de Oxyagrion impunctatum Calvert, 1909 (Odonata - Coenagrionidae). Bol. do Mus. Nac. Zool. 301:1-4.

COSTA, J.M., CARRIÇO, C., SANTOS, T.C. \& MASCARENHAS, B.J.A. 2010. Description of the final instar of Macrothemis heteronycha (Calvert) (Anisoptera: Libellulidae). Zootaxa 2506(1):65-68.

COSTA, J.M., LOURENÇO, A.N. \& VIEIRA, L.P. 2002. Micrathyria pseudhypodidyma sp. n. (Odonata: Libellulidae), com Chave das Espécies do Gênero que Ocorrem no Estado do Rio de Janeiro. Neotrop. Entomol. 31(3):377-389. 
COSTA, J.M., MACHADO, A.B.M., LENCIONI, F.A.A. \& SANTOS, T.C. 2000 Diversidade e distribuição dos Odonata (Insecta) no estado de São Paulo, Brasil: Parte I - Lista das espécies e registros bibliográficos. Publicaçoes Avulsas do Mus. Nac. 80:1-27.

COSTA, J.M., RAVANELLO, C.T. \& SOUZA-FRANCO, G.M. 2008. The larva of Argia croceipennis Selys (Zygoptera: Coenagrionidae). Odonatologica 37(3):265-271.

COSTA, J.M. \& SANTOS, T.C. 2000. Espécie nova de Heteragrion Selys, 1862 do estado do Rio de Janeiro, Brasil (Odonata: Zygoptera: Megapodagrionidae). Bol. do Mus. Nac. do Rio Janeiro / Zool. (411):1-7.

COSTA, J.M., SANTOS, T.C. \& DE SOUZA, L.O.I. 2009. Cyanallagma corbeti sp. nov. from Brazil (Odonata: Coenagrionidae). Int. J. Odonatol. 12(2):323-329.

COSTA, J.M., DE SOUZA, L.I. \& SANTOS, T.C. 2000. Two new species of Oxyagrion Selys, 1876, with a description of five new larvae (Zygoptera: Coenagrionidae). Odonatologica 29(1):1-15.

COSTA, J.M., VIEIRA, L.P. \& LOURENÇO, A.N. 2001. Descrição de três larvas de Erythrodiplax Brauer. 1868 e redescrição das larvas de E. pallida (Needham, 1904) e E. umbrata (Linnaeus. 1758), com chave para identificação das larvas conhecidas das especies brasileiras (Odonata. Libellulidae). Bol. do Mus. Nac. Zool. 465:1-16.

DALZOCHIO, M.S., COSTA, J.M. \& UCHÔA, M.A. 2011. Diversity of Odonata (Insecta) in lotic systems from Serra da Bodoquena, Mato Grosso do Sul State, Brazil. Rev. Bras. Entomol. 55(1):88-94.

DALZOCHIO, M.S., RENNER, S., SGANZERLA, C., PRASS, G., ELY, G.J., SALVI, L.C., DAMETTO, N. \& PÉRICO, E. 2018. Checklist of Odonata (Insecta) in the state of Rio Grande do Sul, Brazil with seven new records. Biota Neotrop. 18(4):e20180551. http://dx.doi.org/10.1590/1676-0611bn-2018-0551 (last access on 26/07/2019)

DUMONT, H.J. \& AL-SAFADI, M.M. 1991. Additions to the dragonfly fauna of Yemen. Not. Odonatol. 3:114-117.

DUNKLE, S.W. 1991. Review of the neotropical damselfly family Dicteriadidae (new spelling), with an annotated bibliography (Zygoptera). Odonatologica 20:401-416.

VON ELLENRIEDER, N. 2009. Databasing dragonflies: State of knowledge in the Neotropical region. Agrion 13(2):58-72.

VON ELLENRIEDER, N. 2011. Odonata (Dragonflies and Damselflies) of the Kwamalasamutu Region, Suriname. In A Rapid Biological Assessment of the Kwamalasamutu region, Southwestern Suriname Conservation International, Arlington, p.56-78.

VON ELLENRIEDER, N. \& GARRISON, R.W. 2006. Rediscovery of Oxyagrion bruchi Navas from Argentina, with a description of its larva (Odonata: Zygoptera: Coenagrionidae). Pan-Pac. Entomol. 82(3/4):362-374.

VON ELLENRIEDER, N. \& GARRISON, R.W. 2007. Dragonflies and Damselflies (Insecta: Odonata) of the Argentine Yungas: Species composition and identification - Scientific Reports n. 7. The Scientific Reports of the Zoological Society "La Torbiera," Milan.

VON ELLENRIEDER, N., MOLINERI, C. \& EMMERICH, D. 2009. Odonata de Uruguay: lista de especies y nuevos registros. Rev. la Soc. Entomológica Argentina 68:227-230.

VON ELLENRIEDER, N. \& MUZÓN, J. 2008. An updated checklist of the odonata from Argentina. Odonatologica 37(1):55-68.

FERREIRA-PERUQUETTI, P. \& TRIVINHO-STRIXINO, S. 2003. Notas sobre relações foréticas entre espécies de Chironomidae e Odonata do Estado de São Paulo, Brasil. Entomotropica 18(2):569-572.

FERREIRA-PERUQUETTI, P.S. \& MARCO JR., P. De. 2002. Efeito da alteração ambiental sobre comunidades de Odonata em riachos de Mata Atlântica de Minas Gerais, Brasil. Rev. Bras. Zool. 19(2):317-327.

FONSECA, C.P. 2005. Caracterização dos Ecossistemas Aquáticos do Cerrado In: SCARIOT, A., SOUSASILVA, J. C.; FELFILI, J. M. (Ed.). Cerrado: Ecologia, Biodiversidade e Conservação. Brasília: Ministério do Meio Ambiente, 2005. p. 25-44.
FLECK, G. 2004. Contribution à la connaissance des Odonates de Guyane française. Les larves de Macrothemispumila Karsch, 1889 et de Brechmorhoga praedatrix Calvert, 1909. Notes biologiques et conséquences taxonomiques (Anisoptera: Libellulidae). Ann. la Société Entomol. Fr. 40(2):177-184

GARCIA-DIAZ, J. 1937. An Ecological Survey of the Fresh Water Insects of Puerto Rico: The Odonata: with new life histories. Cornell Univ, Ithaca.

GARRISON, R.W. 1990. A synopsis of the genus Hetaerina with descriptions of four new species (Odonata: Calopterygidae). Trans. Am. Entomol. Soc. 116(1):175-259.

GARRISON, R.W. 1999. The genus Neoneura, with keys and description of a new species, Neoneura jurzitzai spec. nov.(Zygoptera: Protoneuridae) Odonatologica 28(4):343-375.

GARRISON, R.W. 2006. A synopsis of the genera Mnesarete Cowley, Bryoplathanon gen. nov., and Ormenophlebia gen. nov. (Odonata: Calopterygidae). Contrib. to Sci. Nat. Hist. Museum Los Angeles Cty. 50:61-84.

GARRISON, R.W. 2009. A synopsis of the genus Telebasis (Odonata: Coenagrionidae). Int. J. Odonatol. 12(1):1-121.

GARRISON, R.W., VON ELLENRIEDER, N. \& LOUTON, J.A. 2006. Dragonfly genera of the new word: an illustrated and annotated key to the Anisoptera.

GARRISON, R.W., VON ELLENRIEDER, N. \& LOUTON, J.A. 2010. Damselfly Genera of the New World: An Illustrated and Annotated Key to the Zygoptera. Johns Hopkins University Press, Baltimore, USA.

GUILLERMO-FERREIRA, R. \& BISPO, P.C. 2012. Male and female interactions during courtship of the Neotropical damselfly Mnesarete pudica (Odonata: Calopterygidae). Acta Ethol. 15(2):173-178.

GUILLERMO-FERREIRA, R. \& DEL-CLARO, K. 2011. Resource Defense Polygyny by Hetaerina rosea Selys (Odonata: Calopterygidae): Influence of Age and Wing Pigmentation. Neotrop. Entomol. 40(1):78-84.

GUILLERMO-FERREIRA, R. \& DEL-CLARO, K. 2012a. Reproductive behavior of Acanthagrion truncatum Selys, 1876 (Odonata: Coenagrionidae) Int. J. Odonatol. 15(4):299-304.

GUILLERMO-FERREIRA, R. \& DEL-CLARO, K. 2012b. Territoriality and male-biased sexual size dimorphism in Argia reclusa (Odonata: Zygoptera), Acta Ethol. 15(1):101-105.

GUILLERMO-FERREIRA, R., VILELA, D.S., DEL-CLARO, K. \& BISPO, P. 2016. Erythrodiplax ana sp. nov. (Odonata: Libellulidae) from Brazilian palm swamps. Zootaxa 4158(2):292.

GUIMARÃES, A.J.M.; ARAÚJO, G.M \& CORRÊA, G.F. 2002. Estrutura fitossociológica em área natural e antropizada de uma vereda em Uberlândia, MG. Acta Bot. Brasi. 16:317-329.

HANAUER, G., RENNER, S. \& PÉRICO, E. 2014. Inventariamento Preliminar da Fauna de libélulas (Odonata) em quatro municípios do vale do Taquari/ RS. Rev. Destaques Acadêmicos 6(3):36-45.

IBGE. 2019. Mapas. https://mapas.ibge.gov.br/ (last access on 20/07/2019)

IUCN. 2019. IUCN Red List of Threatened species. https://www.iucnredlist. org/ (last access on 20/07/2019)

JURZITZA, G. 1981. Wiederauffindung der Neoneura waltheri Selys, $1866 \mathrm{im}$ argentinischen Nationalpark Iguazú, sowie Erstbeschreibung des adulten Männchens und des Weibchens (Zygoptera: Protoneuridae). Odonatologica 10:323-331.

KOROIVA, R., PEPINELLI, M., RODRIGUES, M.E., ROQUE, F.O., LORENZLEMKE, A.P. \& KVIST, S. 2017a. DNA barcoding of odonates from the Upper Plata basin: database creation and genetic diversity estimation. PLoS One 8(12):e0182283.

KOROIVA, R., RODRIGUES, M.E., VALENTE-NETO, F. \& ROQUE, F.O. 2017b. Odonates from Bodoquena Plateau: checklist and information about endangered species. Biota Neotrop. 16(3):e20160310. http://dx.doi org/10.1590/1676-0611-bn-2016-0310 (last access on 26/07/2019). 
LENCIONI, F.A.A. 2005. Damselflies of Brazil: An Illustrated Identification Guide, Volume 1: Non-Coenagrionidae Families. All Print Editora, São Paulo, Brazil

LENCIONI, F.A.A. 2006. Damselflies of Brazil: An Illustrated Identification Guide, Volume 2: Coenagrionidae. All Print Editora, São Paulo, Brazil.

LENCIONI, F.A.A. 2011. Rediscovery of Telebasis erythrina (Selys, 1876), with notes on habitat and conservation (Zygoptera: Coenagrionidae). Odonatologica 40(4):327-331.

LENCIONI, F.A.A. 2017. Damselflies of Brazil - an illustrated identification guide - Southeast region. E-book.

LEONARD, J.W. 1977. A revisionary study of the genus Acanthagrion (Odonata: Zygoptera). Misc. Publ. Museum Zool. Univ. Michigan 1531-173.

LOUTON, J.A., GARRISON, R.W. \& FLINT, O.S. 1996. The Odonata of Parque Nacional Manu, Madre de Dios, Peru; natural history, species richness and comparisons with other Peruvian sites. In Manu, the biodiversity of southeastern Peru (D. Wilson \& A. Sandoval, eds) Smithsonian Institute Press, Washington, D.C., p.431-449.

MACHADO, A.B.M. 1964. Duas novas Epipleoneura dos Rios Paru de Oeste e Amapari (Odonata-Protoneuridae). Bol. do Mus. Para. Emilio Goeldi, Zool. 51:1-15.

MACHADO, A.B.M. 1985. Estudos sobre Protoneurídeos neotropicais. 6. Três novas espécies de Epipleoneura da região amazônica.(Odonata, Zygoptera). Rev. Bras. Biol. 45:695-701.

MACHADO, A.B.M. 1988. Heteragrion petiense spec. nov., from the state of Minas Gerais, Brazil (Zygoptera: Megapodagrionidae). Odonatologica 17(3):267-274.

MACHADO, A.B.M. 1998. Insetos. In Livro Vermelho das Espécies Ameaçadas de Extinção da Fauna de Minas Gerais (A. B. Machado, G. A. B. Fonseca, R. B. Machado, L. M. S. Aguiar, \& L. V. Lins, eds) Fundação Biodiversitas, Belo Horizonte, p.495-497.

MACHADO, A.B.M. 2000. Studies on Neotropical Protoneuridae. 10. Forcepsioneura lucia sp. n. from the Parque Estadual Rola Moça, Minas Gerais, Brazil (Odonata, Zygoptera). Bol. do Mus. Biol. Mello Leitão, Nov. Série 11/12127-134.

MACHADO, A.B.M. 2002. Studies on neotropical Protoneuridae. 13: The types of Neoneura rufithorax Selys (Zygoptera). Not. Odonatol. 5(9):115-116.

MACHADO, A.B.M. 2005a. Lauromacromia bedei sp. nov. from the State of Minas Gerais, Brazil (Odonata, Corduliidae). Rev. Bras. Entomol. 49(4):453-456.

MACHADO, A.B.M. 2005b. Neocordulia matutuensis spec. nov. from Brazil (Anisoptera: Corduliidae). Odonatologica 34(3):299-302.

MACHADO, A.B.M. 2006. Three new species of Heteragrion Selys, from Brazil with redescription of the holotype of H. Dorsale Selys (Odonata, Megapodagrionidae). Rev. Bras. Zool. 23(4):1062-1070.

MACHADO, A.B.M. 2007a. Leptagrion afonsoi sp. n. from the state of Minas Gerais, Brazil (Odonata: Coenagrionidae). Lundiana 7:125-126.

MACHADO, A.B.M. 2007b. Studies on neotropical Protoneuridae. 20. Neoneura kiautai spec. nov. from Southeastern Brazil (Zygoptera, Protoneuridae). In Odonata: Biology of Dragonflies (B. K. Tyagi, ed.) Scientific Publishers, Jodhpur, p.25-32.

MACHADO, A.B.M. 2010. Oxyagrion mirnae spec. nov. from Brazil (Zygoptera: Coenagrionidae). Odonatologica 39(4):353-356.

MACHADO, Â.B.M. 2015. Heteragrion thais sp nov from the Atlantic Forest of Brazil (Odonata: Heteragrionidae). Odonatologica 44(3):391-396.

MACHADO, A.B.M. \& BEDÊ, L.C. 2006. Heteragrion tiradentense spec. nov. from the state of Minas Gerais, Brazil (Zygoptera: Megapodagrionidae). Odonatologica 35(1):47-54.

MACHADO, A.B.M. \& BEDÊ, L.C. 2015. Two new genera and nine new species of damselflies from a localized area in Minas Gerais, Brazil (Odonata: Zygoptera). Int. J. Odonatol. 18(4):269-296.

MACHADO, A.B.M., MESQUITA, H.G. \& MACHADO, P.A.R. 1991. Contribuição ao conhecimento dos Odonatos da Estação Ecológica de Maracá-Roraima. Acta Amaz. 21:159-173.
MACHADO, A.B.M. \& DE SOUZA, M.M. 2014. A remarkable new species of Heteragrion from Brazil (Odonata: Megapodagrionidae). Int. J. Odonatol. 17(2-3):95-99.

MITRA, A. 2000. Annotated Odonata inventory of the Asan Reservoir, Dehra Dun, India. Not. Odonatol. 5:57-60.

MONTEIRO-JÚNIOR, C.S., COUCEIRO, S.R.M., HAMADA, N. \& JUEN, L. 2013. Effect of vegetation removal for road building on richness and composition of Odonata communities in Amazonia, Brazil. Int. J. Odonatol. 17:1-13

NEISS, U.G. 2012. Taxonomia de Odonata (Insecta), com ênfase na caracterização morfológica e biologia de larvas, na Amazônia Central, Brasil. Ph.D. Thesis - Instituto Nacional de Pesquisa da Amazônia (INPA), Manaus.

NOBRE, C.E. \& LAGO CARVALHO, A. 2014. Odonata of Itatira, a Brazilian semi-arid area in the state of Ceará. Int. J. Odonatol. 17(2-3):73-80.

NÓBREGA, C.C. \& DE MARCO, P. 2011. Unprotecting the rare species: A niche-based gap analysis for odonates in a core Cerrado area. Divers. Distrib. 17(3):491-505.

OLDRINI, B.B. \& MASCARENHAS, B.J. de A. 2005. Descrição da larva de Idiataphe longipes (Odonata, Libellulidae, Trameini). Iheringia. Série Zool. 95(4):431-433.

OLIVEIRA, G.C., ARAÚJO, G.M., \& BARBOSA, A.A.A. 2009. Florística e zonação de espécies vegetais em veredas no Triângulo Mineiro, Brasil. Rodriguésia, 1077-1085.

PAIVA-SILVA, D. de, DE MARCO, P. \& RESENDE, D.C. 2010. Adult odonate abundance and community assemblage measures as indicators of stream ecological integrity: A case study. Ecol. Indic. 10(3):744-752.

DEL PALACIO, A. \& MUZÓN, J. 2016. Redescription of Erythrodiplax pallida (Needham, 1904) (Odonata: Libellulidae). Int. J. Odonatol. 19(1-2):23-30.

PAULSON, D.R. 1998. Possible morphological and behavioral male mimicry in a libellulid dragonfly, Erythrodiplax umbrata (L.)(Anisoptera: Libellulidae). Odonatologica 27(2):249-252.

PAULSON, D.R. 2009a. Coryphaeschna adnexa. IUCN Red List Threat. Species. https://www.iucnredlist.org/search (last access on 12/03/2014)

PAULSON, D.R. 2009b. Erythemis vesiculosa. IUCN Red List Threat. Species. https://www.iucnredlist.org/search (last access on 12/03/2014)

PAULSON, D.R. 2017a. Tholymis citrina. IUCN Red List Threat. Species. http://dx.doi.org/10.2305/IUCN.UK.2017-3.RLTS.T49254464A49256177. en (last access on 26/07/2019)

PAULSON, D.R. 2017b. Tramea calverti. IUCN Red List Threat. Species. http:// dx.doi.org/10.2305/IUCN.UK.2017-3.RLTS.T164926A80684694.en (last access on $26 / 07 / 2019$ )

PESSACQ, P. \& COSTA, J.M. 2007. Three new species of Peristicta Hagen in Selys (Odonata: Zygoptera: Protoneuridae) from Brazil. Neotrop. Entomol. 36(1):46-52.

PESTANA, G.C., CAROMANO, T.G. \& FERREIRA, R.G. 2018. Sexual ornamentation triggers rival aggressiveness in the Neotropical damselfly Hetaerina longipes (Odonata: Calopterygidae). Odonatologica 47(1/2):121132.

PINTO, A.P. \& ALMEIDA, M.V. de. 2016. A taxonomic synopsis of South American Cyanogomphini Carle with description of Cyanogomphus angelomachadoi sp. nov. from the Cerrado of Brazil (Odonata: Gomphidae). Zootaxa 4078(1):38-69.

PINTO, N.S., NETO, J.H., RIBEIRO, V., RODRIGUES, A.R., BRANDÃO, B.R. \& ROCHA, C.O. 2013. Efeito da Presença de Vizinhos sobre o Comportamento Territorial de Perithemis mooma (Kirby) (Anisoptera: Libellulidae). EntomoBrasilis 6(2):104-107.

RÁCENIS, J. 1960. Cuatro nuevas especies del género Epipleoneura (Odonata: Protoneuridae). Acta Biológica Venez. 3:35-42.

RENNER, S., PÉRICO, E. \& SAHLÉN, G. 2016a. List of Odonates from the Floresta Nacional de São Francisco de Paula (FLONA - SFP), with two new distribution records for Rio Grande do Sul, Brazil. Biota Neotrop. 16(3):e20150132. http://dx.doi.org/10.1590/1676-0611-BN-2015-0132 (last access on 26/07/2019) 
RENNER, S., PÉRICO, E. \& SAHLÉN, G. 2016b. Man-made lakes form speciesrich dragonfly communities in the Brazilian Atlantic Forest. Odonatologica 45(3/4):135-154.

RODRIGUES, M.E., MOURA, E.B., KOROIVA, R., BORGES, A.C.P. \& ROQUE, F. de O. 2018. Survey of Dragonflies (Odonata) in Palm Swamps of Cerrado Hotspot. Entomol. News 128(1):24-38.

RODRIGUES, M.E. \& ROQUE, F. de O. 2017. Checklist de Odonata do Estado de Mato Grosso do Sul, Brasil. Iheringia. Série Zool. 107(suppl):1-4.

SALGADO, L.G.V., CARVALHO, A. do L. \& PINTO, Â.P. 2013. Larval taxonomy of Macrothemis Hagen, 1868 (Odonata: Libellulidae), with descriptions of four larvae and a key to the fourteen known species. Zootaxa 3599(3):229-245.

SANTOS, N.D. 1944. Libellulidae coligidos em Ilha seca (Estado de São Paulo), Salobra e Bodoquena (Estado de Mato Grosso) pela Comissão Científic do Instituto Oswaldo Cruz (Insecta: Odonata). Bol. do Mus. Nac. Série Zool. 16:1-10

SANTOS, N.D. 1945. Contribuição ao conhecimento da fauna de Pirassununga. Estado de São Paulo. 1-Gênero Dythemis Hagen, com a descrição de duas espécies novas e notas sôbre outras espécies (Libellulidae: Odonata). Bol. do Mus. Nac. 40:1-11.

SANTOS, N.D. 1950. A especiação no gênero Nephepeltia (Libellulidae: Odonata). Ph.D. Thesis - Universidade do Brasil, Rio de Janeiro.

SANTOS, N.D. 1970. Contribuição ao conhecimento da fauna do estado da Guanabara 71. Notas sobre a ninfa e o imago de Limnetron debile (Karsch, 1891) Foerster, 1914 (Odonata, Aeshnidae). Atas Soc. Biol. do Rio Janeiro 13:15-17.

SANTOS, T.C., COSTA, J.M. \& CARRIÇO, C. 2010. A new species of Neocordulia Selys, 1882 (Odonata: Corduliidae) from Minas Gerais State, Brazil. Biota Neotrop. 10(2):89-91. http://dx.doi.org/10.1590/S167606032010000200011 (last access on 26/07/2019)

SOUZA, L.O.I. 2003. A influência dos fatores ambientais na distribuição da fauna de Odonata (Insecta) em riachos da Serra da Bodoquena, MS. Master dissertation - Universidade Federal de Mato Grosso do Sul, Dourados.
DE SOUZA, M.M., PIRES, E.P., BRUNISMANN, Â.G., MILANI, L.R. \& PINTO, Â.P. 2017. Dragonflies and damselflies (Odonata) from the wetland of the Rio Pandeiros, northern region of Minas Gerais State, Brazil, with a description of the male of Archaeogomphus vanbrinki Machado (Anisoptera: Gomphidae). Int. J. Odonatol. 20(1):13-26.

DE SOUZA, M.M., SOUZA, B., PEREIRADE, M.C.S. de A. \& MACHADO, A.B.M. 2013. List of odonates from Mata do Baú, Barroso, Minas Gerais, Brazil. Check List 9(6):1367-1370.

TENNESSEN, K.J. 2004. Acanthagrion aepiolum sp. nov. from South America (Odonata: Coenagrionidae). Int. J. Odonatol. 7(1):79-86.

TENNESSEN, K.J. 2015. Four new species of Calvertagrion St. Quentin from South America (Odonata: Coenagrionidae). Odonatologica 44:397-430

VILELA, D.S., FERREIRA, R.G. \& DEL-CLARO, K. 2016. The odonata community of a brazilian vereda: seasonal patterns, species diversity and rarity in a palm swamp environment. Biosci. J. 32(1):486-495.

VILELA, D.S., GUILLERMO-FERREIRA, R. \& CORDERO-RIVERA, A. 2018a. Description of the female of Dicterias atrosanguinea Selys 1853, with notes on male genital ligula and male behavior (Odonata: Dicteriadidae). Zootaxa 4374(3):441.

VILELA, D.S., GUILLERMO-FERREIRA, R., DEL-CLARO, K. \& CORDERO-RIVERA, A. 2018b. Argia angelae (Odonata: Zygoptera: Coenagrionidae) sp. nov. from Chapada dos Guimarães, Mato Grosso, Brazil. Zootaxa 4415(3):549-560.

VILELA, D. S., KOROIVA, R., \& GUILLERMO-FERREIRA, R. 2019. Heteragrion denisye sp. nov.(Odonata: Zygoptera: Heteragrionidae), a notable species from Serra da Canastra, Minas Gerais, Brazil. Zootaxa 4671(4):589-594. 